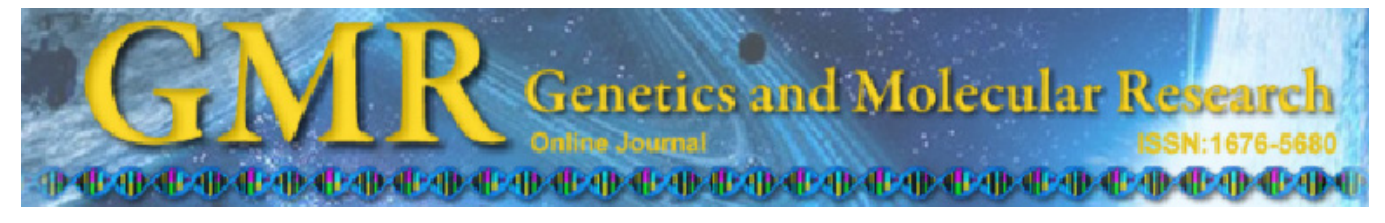

\title{
Cytochrome c oxidase subunit I barcoding of the green bee-eater (Merops orientalis)
}

\author{
I.A. Arif ${ }^{1,3}$, H.A. Khan ${ }^{1,2,3}$, M. Shobrak ${ }^{3,4}$ and J. Williams ${ }^{5}$ \\ ${ }^{1}$ Department of Botany and Microbiology, College of Science, \\ King Saud University, Riyadh, Saudi Arabia \\ ${ }^{2}$ Department of Biochemistry, College of Science, \\ King Saud University, Riyadh, Saudi Arabia \\ ${ }^{3}$ Molecular Fingerprinting and Biodiversity Unit, \\ Prince Sultan Research Chair for Environment and Wildlife, \\ King Saud University, Riyadh, Saudi Arabia \\ ${ }^{4}$ Department of Biology, College of Science, Taif University, \\ Taif, Saudi Arabia \\ ${ }^{5}$ Department of Evolution, Ecology and Organismal Biology, \\ Ohio State University, Columbus, USA \\ Corresponding author: H.A. Khan \\ E-mail: khan_haseeb@yahoo.com / haseeb@ksu.edu.sa
}

Genet. Mol. Res. 10 (4): 3992-3998 (2011)

Received August 11, 2011

Accepted September 13, 2011

Published October 21, 2011

DOI http://dx.doi.org/10.4238/2011.October.21.2

ABSTRACT. DNA barcoding using mitochondrial cytochrome c
oxidase subunit I (COI) is regarded as a standard method for species
identification. Recent reports have also shown extended applications of
COI gene analysis in phylogeny and molecular diversity studies. The
bee-eaters are a group of near passerine birds in the family Meropidae.
There are 26 species worldwide; five of them are found in Saudi Arabia.
Until now, GenBank included a COI barcode for only one species of
bee-eater, the European bee-eater (Merops apiaster). We sequenced the
694-bp segment of the COI gene of the green bee-eater M. orientalis
and compared the sequences with those of $M$. apiaster. Pairwise
sequence comparison showed 66 variable sites across all the eight
sequences from both species, with an interspecific genetic distance 
of 0.0362 . Two and one within-species variable sites were found, with genetic distances of 0.0005 and 0.0003 for $M$. apiaster and $M$. orientalis, respectively. This is the first study reporting barcodes for M. orientalis.

Key words: DNA barcoding; Green bee-eater; European bee-eater; Cytochrome oxidase I; COI; Phylogenetics

\section{INTRODUCTION}

Bee-eaters, which belong to the Meropidae, order Coraciiformes, are insectivorous birds characterized by richly colored plumage, slender bodies and elongated central tail feathers. There are 26 species worldwide, where most of them are found in Africa, but others occur in southern Europe, Madagascar, Australia and New Guinea (Dickinson, 2003). The green bee-eater (Merops orientalis), white-throated bee-eater (Merops albicollis), blue-cheeked beeeater (Merops persicus) and European bee-eater (Merops apiaster) are found in Saudi Arabia. The low level of morphological diversity in the family is in stark contrast to their high diversity in ecological and life history traits. Significant variation has been observed in the density of bee-eater populations depending on vegetation structure, food (insects) availability, climatic conditions and human disturbance (Asokan et al., 2003). Populations of bee-eaters are in decline owing to the scarcity of suitable prey, a result of widespread application of pesticides and because of unwarranted shooting for sport (del Hoyo et al., 2001).

A resident of Saudi Arabia, the green bee-eater is found widely distributed across subSaharan Africa from Senegal and Gambia to Ethiopia, the Nile valley, western Arabia and Asia through India to Vietnam. It is about $16-18 \mathrm{~cm}$ long with about $5 \mathrm{~cm}$ made up by the elongated central tail-feathers. The sexes are not visually distinguishable. The monomorphic European bee-eater breeds in southern Europe and in parts of northern Africa and western Asia. It is migratory, wintering in tropical Africa, India and Sri Lanka. It has brown and yellow upper parts, whilst the wings are green and the beak is black. It can reach a length of $27-29 \mathrm{~cm}$, including the two elongated central tail feathers.

The central goal of systematists and evolutionary biologists is the proper identification of species to provide a clear picture of exact organismal diversity and of past evolutionary history. DNA barcoding is a method of species identification using mitochondrial cytochrome c oxidase subunit I (COI) sequences with the potential to discriminate closely related species across diverse phyla in the animal kingdom (Hebert et al., 2003a,b). Using a large dataset of North American birds, it has been concluded that DNA barcoding can be effectively applied across the geographical and taxonomic expanse of bird species (Kerr et al., 2007). Several studies have shown that COI-based DNA barcoding has potential for discrimination among species (Hebert et al., 2004; Kerr et al., 2007, 2009; Tavares and Baker, 2008; Bravo et al., 2008). However, due to the scarcity of barcoding data, a consensus has not been firmly established to assign a sequence threshold to screen for splits referred to as putative species. Therefore, a survey of intraspecific barcodes from different geographical regions has been strongly recommended (Cai et al., 2010).

Despite the successful application of DNA barcoding for species identification of birds from different regions (Hebert et al., 2004; Yoo et al., 2006; Vilaça et al., 2006; Kerr 
et al., 2007, 2009; Chaves et al., 2008; Cai et al., 2010), few barcodes of birds from Saudi Arabian have been determined (Khan et al., 2010). Here, we sequenced the 694-bp region of the COI gene of Merops orientalis and compared these sequences to the previously published sequences of another species, Merops apiaster. At present, the COI barcodes of only one species (Merops apiaster) of bee-eaters are available in GenBank. This study provides the first report on the DNA barcode of Merops orientalis.

\section{MATERIAL AND METHODS}

Tissues (thigh muscle) were collected from 4 frozen specimens of Merops orientalis. All these 4 birds were collected from an area called Al Hayathem at Al Kharj, 100 km southeast of Riyadh, Saudi Arabia, located at N 24 19.603 E47 21.982.

DNA was extracted from the blood samples using the DNeasy Blood and Tissue kit (Qiagen GmbH, Germany). The extracted DNA was dissolved in $200 \mu \mathrm{L}$ elution buffer and stored at $-20^{\circ} \mathrm{C}$.

COI sequences were amplified using the primer pair of BirdF1 and BirdR1 (Kerr et al., 2007) and FideliTaq PCR master mix (GE Healthcare) in a reaction volume of $30 \mu \mathrm{L}$. The PCR conditions included a denaturation step $\left(1 \mathrm{~min}\right.$ at $\left.94^{\circ} \mathrm{C}\right)$ followed by six cycles of $1 \mathrm{~min}$ at $94^{\circ} \mathrm{C}, 1.5 \mathrm{~min}$ at $45^{\circ} \mathrm{C}$, and $1.5 \mathrm{~min}$ at $72^{\circ} \mathrm{C}$, followed in turn by 35 cycles of $1 \mathrm{~min}$ at $94^{\circ} \mathrm{C}, 1.5 \mathrm{~min}$ at $55^{\circ} \mathrm{C}$, and $1.5 \mathrm{~min}$ at $72^{\circ} \mathrm{C}$, and a final extension for $5 \mathrm{~min}$ at $72^{\circ} \mathrm{C}$. The PCR products were separated by electrophoresis on a $1 \%$ agarose gel stained with ethidium bromide. The PCR products were purified using MicroSpin S300 columns (GE Healthcare) before being sequenced using BigDye Terminator Cycle Sequencing Kit (Applied Biosystems, USA) on a 3130XL genetic analyzer (Applied Biosystems). For each sample, two sets of sequencing reactions were performed using the forward and reverse primers for high accuracy.

For comparative evaluation of COI barcode sequences of Merops orientalis, we searched the GenBank nucleotide database and found only 5 barcode records of a single species, European bee-eater (Merops apiaster). Of these, we omitted the short sequences of 1 record (659 bp) and downloaded 4 sequences (Accessions; GQ482161 to GQ482164) with 694 nucleotides.

The sequences were aligned by ClustalW (Larkin et al., 2007) and then subjected to neighbor joining (NJ) and unweighted pair group method with arithmetic mean (UPGMA) for phylogenetic analyses using the evolutionary distances computed by the maximum composite likelihood method (Sneath and Sokal, 1973, Tamura et al., 2004). Both these analyses were performed using MEGA4 software, and the bootstrap consensus trees inferred from 500 replicates were taken to represent the node support for the clades observed (Felsenstein, 1985; Tamura et al., 2007).

\section{RESULTS}

We sequenced the mitochondrial COI gene segment (694 bp) from the 4 specimens of Merops orientalis; all these nucleotide sequences have been deposited in GenBank with the accession numbers HQ168063 to HQ168066. The other 4 sequences of a different species (Merops apiaster) that we retrieved from GenBank had the same length with a 
common start position. However, we deleted the first nucleotide from all the sequences to ensure the first nucleotide of the modified sequences (693 bp) was the start position of codon 1 .

The pair-wise sequence comparison of the COI gene showed $66(9.52 \%)$ variable sites across all the individuals, whereas within-species variable sites were found to be 2 $(0.28 \%)$ and $1(0.14 \%)$ for Merops apiaster and Merops orientalis, respectively (Figure 1). The COI genetic distances between the 8 individuals varied from 0.000 to 0.037 (Table 1). The evolutionary divergence over sequence pairs between species was 0.036 , while intraspecific divergence was found to be 0.0005 for Merops apiaster and 0.0003 for Merops orientalis.

Phylogenetic analysis using the 693-bp nucleotide segment of COI clearly discrimi-

\begin{tabular}{|c|c|}
\hline & 15789224455678891234667788900223356690122345668112246779013466789 \\
\hline & 384210394769570380243240958469476976998446540286342561094059836543 \\
\hline Merops.apiaster.GQ482164 & CAACGCTTATGCTAATTTTATCGCTTGTGCAGCGTTGCGTCATTTACTACCCCTTGATAATCCGTA \\
\hline Merops.apiaster.GQ482162 & .... т. \\
\hline Merops.apiaster.GQ482163 & $\cdots \cdots$ \\
\hline Merops.apiaster.GQ482161 & $\ldots \ldots \ldots \ldots \ldots \ldots \ldots$ \\
\hline Merops.orientalis.1 & TGGTA. CCGCATAGGCCCCCCTATAAACATGATAC.TTACTGCCCGTCGTATTCCAGCTGCTTACG \\
\hline Merops.orientalis.2 & TGGTA. CCGCATAGGCCCCCCTATAAACATGATAC.TTACTGCCCGTCGTATTCCAGCTGCTTACG \\
\hline Merops.orientalis.3 & TGGTA. CCGCATAGGCCCCCCTATAAACATGATAC.TTACTGCCCGTCGTATTCCAGCTGC.TACG \\
\hline Merops.orientalis. 4 & TGGTA. CCGCATAGGCCCCCCTATAAACATGATAC.TTACTGCCCGTCGTATTCCAGCTGC.TACG \\
\hline
\end{tabular}

Figure 1. Sequence variations in COI gene showing the variable sites among the 8 individuals (4 each from Merops apiaster and Merops orientalis). Between species, there are 66 variable sites out of 693 nucleotides. Within species, there are 2 (Merops apiaster) and 1 (Merops orientalis) variable sites. The identical sites are represented by dots.

Table 1. Pair-wise distance comparisons showing the actual number of variable sites (upper right) and the number of base substitutions per site (lower left; rounded to three decimal places) using the maximum composite likelihood model (Tamura et al., 2007).

\begin{tabular}{|c|c|c|c|c|c|c|c|c|}
\hline & MA 1 & MA 2 & MA 3 & MA 4 & MO 1 & MO 2 & MO 3 & MO 4 \\
\hline MA 1 & & 1 & 0 & 1 & 64 & 64 & 63 & 63 \\
\hline MA 2 & 0.000 & & 1 & 2 & 65 & 65 & 64 & 64 \\
\hline MA 3 & 0.000 & 0.000 & & 1 & 64 & 64 & 63 & 63 \\
\hline MA 4 & 0.000 & 0.001 & 0.000 & & 65 & 65 & 64 & 64 \\
\hline MO 1 & 0.036 & 0.037 & 0.036 & 0.037 & & 0 & 1 & 1 \\
\hline MO 2 & 0.036 & 0.037 & 0.036 & 0.037 & 0.000 & & 1 & 1 \\
\hline MO 3 & 0.036 & 0.036 & 0.036 & 0.036 & 0.000 & 0.000 & & 0 \\
\hline MO 4 & 0.036 & 0.036 & 0.036 & 0.036 & 0.000 & 0.000 & 0.000 & \\
\hline
\end{tabular}

Abbreviations are: MA 1 (Merops apiaster, GQ482164); MA 2 (Merops apiaster, GQ482162); MA 3 (Merops apiaster, GQ482163); MA 4 (Merops apiaster, GQ482161); MO 1 (Merops orientalis, HQ168063); MO 2 (Merops orientalis, HQ168064); MO 3 (Merops orientalis, HQ168065); MO 4 (Merops orientalis, HQ168066).

nated both species of bee-eaters (Figure 2). However, the translation of nucleotide sequences revealed identical amino acid sequences for all 8 specimens.

\section{DISCUSSION}



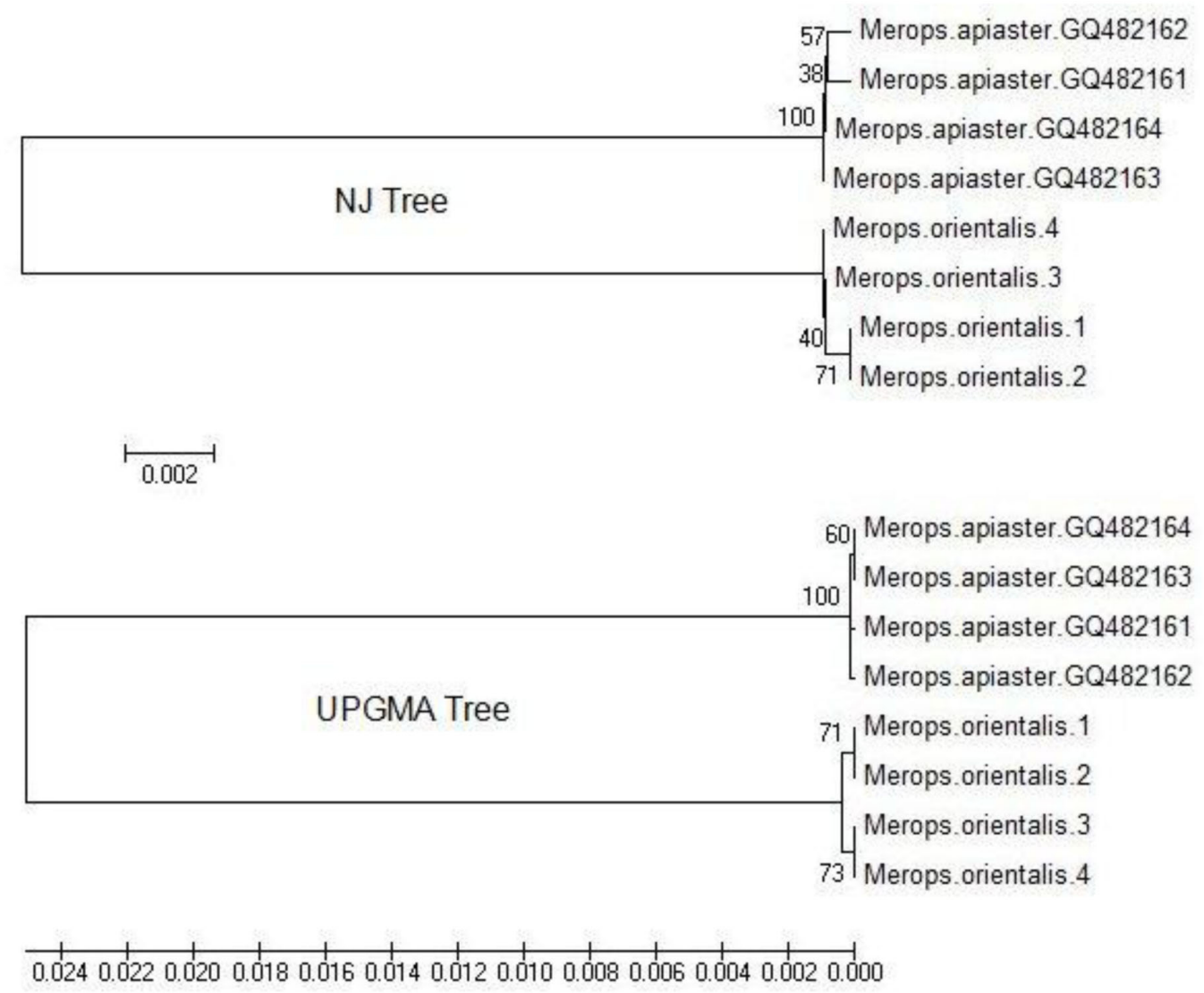

Figure 2. NJ and UPGMA trees showing the relationship between the two different species of bee-eaters, the resident Merops orientalis and migratory Merops apiaster.

Burt (2004) scored thirty plumage regions for color, pattern and shape to describe phylogenetic relationship among various species and subspecies of bee-eaters. Although this subjective method resulted in consistent patterns across shallow portions of the trees, considerable uncertainty remained for the placement of deep branches. As a result, he suggested the need of additional data based on nucleotide sequences for phylogenetic accuracy (Burt, 2004). Later on, Marks et al. (2007) performed a phylogenetic analysis of bee-eaters using the DNA sequence data from the second subunit of mitochondrial nicotinamide adenine dinucleotide dehydrogenase gene (ND2, $1041 \mathrm{bp}$ ) and two nuclear introns: the fifth intron of nuclear b-fibrinogen gene (BFib5, 604 bp) and the fifth intron of transforming growth factor, b2 gene (TGFb2, $566 \mathrm{bp}$ ). However, COI barcodes for bee-eaters are largely unexplored. Kerr et al. (2009) have highlighted the importance of DNA barcodes in avian research as twofold, i) preliminary investigations that offer fresh insight to aid the ongoing effort to refine avian taxonomy and ii) a comprehensive library of COI sequences to provide an invaluable tool for species assignment when morphological differences are difficult to measure. 
The results of this study clearly showed the discriminatory power of COI barcodes for species identification. The interspecific genetic variation was found to be high $(9.52 \%)$ as compared to our recent study on partridges (7.66\%) (Khan et al., 2010) using the same sized COI gene segment. Phylogenetic analysis separated the two different species of bee-eaters into distinct clades with high bootstrap support (Figure 2). Such a high level of differentiation between Merops apiaster and Merops orientalis, observed in our study, may be attributed to their resident and migratory characteristics, respectively. Marks et al. (2007) have grouped the bee-eaters into two well-supported clades defined on ecological lines: sedentary or migratory species. The sequences from the 4 samples of Merops apiaster showed only 2 within-species variable sites (Figure 1) which is in accordance with the negligible level of differentiation observed in Merops apiaster collected from Kuwait and Malawi (Marks et al., 2007). Despite an overall low intraspecific variation in both species, Merops apiaster showed a high number of within-species variable sites in relation to Merops orientalis (Figure 2). The understanding of phylogenetic relationship within the group is important to make a valid comparative study of various traits of bee-eaters (Burt, 2004), while more concentrated taxon sampling and more intraspecific studies in general are needed to gain a better understanding of genetic structure of bee-eaters (Marks et al., 2007).

In conclusion, COI barcoding is an effective molecular tool for species identification and phylogenetic inference. Since this technique is based on molecular-level variation, it offers a greater accuracy and authenticity than the plumage-based subjective phylogeny of birds. The latter methodology is devoid of conventional quantitative analysis such as bootstrapping and also tends to be problematic due to high levels of homoplasy in color pattern leading to a weaker phylogenetic signal. This is the first report on COI barcodes of the green bee-eater and would be helpful for future molecular studies in these birds.

\section{ACKNOWLEDGMENTS}

Research supported by National Plan for Science and Technology (NPST) Program by King Saud University, Project Number BIO1116-02-10. The technical assistance of Mr. Anis Ahamed and Mr. Ahmad Mustafa is highly appreciated.

\section{REFERENCES}

Asokan S, Thiyagesan K, Nagarajan R and Kanakasabai R (2003). Studies on Merops orientalis Latham 1801 with special reference to its population in Mayiladuthurai, Tamil Nadu. J. Environ. Biol. 24: 477-482.

Bravo JP, Silva JL, Munhoz RE and Fernandez MA (2008). DNA barcode information for the sugar cane moth borer Diatraea saccharalis. Genet. Mol. Res. 7: 741-748.

Burt DB (2004). Plumage-based phylogenetic analysis of Merops bee-eaters. Ibis 146: 481-492.

Cai Y, Yue B, Jiang W, Xie S, et al. (2010). DNA barcoding on subsets of three families in Aves. Mitochondrial. DNA 21: $132-137$

Chaves AV, Clozato CL, Lacerda DR, Sari EH, et al. (2008). Molecular taxonomy of Brazilian tyrant-flycatchers (Passeriformes: Tyrannidae). Mol. Ecol. Res. 8: 1169-1177.

del Hoyo J, Elliott A and Sargatal J (2001). Handbook of the Birds of the World. In: Mousebirds to Hornbills Lynx Editions, Barcelona,

Dickinson EC (2003). The Howard and Moore Complete Checklist of the Birds of the World. Princeton University Press, Princeton, New Jersey.

Felsenstein J (1985). Confidence limits on phylogenies: An approach using the bootstrap. Evolution 39: 783-791.

Hebert PD, Cywinska A, Ball SL and deWaard JR (2003a). Biological identifications through DNA barcodes. Proc. Biol. Sci. 270: 313-321. 
Hebert PD, Ratnasingham S and deWaard JR (2003b). Barcoding animal life: cytochrome c oxidase subunit 1 divergences among closely related species. Proc. Biol. Sci. 270 (Suppl 1): S96-S99.

Hebert PD, Stoeckle MY, Zemlak TS and Francis CM (2004). Identification of Birds through DNA Barcodes. PLoS Biol. 2: $\mathrm{e} 312$.

Kerr KC, Stoeckle MY, Dove CJ, Weigt LA, et al. (2007). Comprehensive DNA barcode coverage of North American birds. Mol. Ecol. Notes 7: 535-543.

Kerr KC, Birks SM, Kalyakin MV, Red'kin YA, et al. (2009). Filling the gap - COI barcode resolution in eastern Palearctic birds. Front Zool. 6: 29.

Khan HA, Arif IA and Shobrak M (2010). DNA barcodes of Arabian partridge and philby’s rock partridge: implications for phylogeny and species identification. Evol. Bioinform. Online 6: 151-158.

Larkin MA, Blackshields G, Brown NP, Chenna R, et al. (2007). Clustal W and Clustal X version 2.0. Bioinformatics 23: 2947-2948.

Marks BD, Weckstein JD and Moyle RG (2007). Molecular phylogenetics of the bee-eaters (Aves: Meropidae) based on nuclear and mitochondrial DNA sequence data. Mol. Phylogenet. Evol. 45: 23-32.

Sneath PHA and Sokal RR (1973). Numerical Taxonomy. Freeman, San Francisco.

Tamura K, Nei M and Kumar S (2004). Prospects for inferring very large phylogenies by using the neighbor-joining method. Proc. Natl. Acad. Sci. U. S. A. 101: 11030-11035.

Tamura K, Dudley J, Nei M and Kumar S (2007). MEGA4: molecular evolutionary genetics analysis (MEGA) software version 4.0. Mol. Biol. Evol. 24: 1596-1599.

Tavares ES and Baker AJ (2008). Single mitochondrial gene barcodes reliably identify sister-species in diverse clades of birds. BMC Evol. Biol. 8: 81.

Vilaça ST, Lacerda DR, Sari HER and Santos FR (2006). DNA-based identification applied to Thamnophilidae (Passeriformes) species: the first barcodes of Neotropical birds. Rev. Bras. Ornitol. 14: 7-13.

Yoo HS, Eah JY, Kim JS, Kim YJ, et al. (2006). DNA barcoding Korean birds. Mol. Cells 22: 323-327. 